\title{
PORNOGRAFI DALAM BALUTAN FILM BERTEMA HOROR MISTIK DI INDONESIA
}

\author{
Erni Herawati \\ Jurusan Marketing Communication, Fakultas Ekonomi dan Komunikasi, BINUS University \\ Jln. K.H.Syahdan No. 9, Palmerah, Jakarta Barat 11480
}

\begin{abstract}
The film industry in Indonesia has been through ups and downs. As an industry, thus there are usual things the film creators done to take financial benefit from the film industry. Some researches show that messages brought by mass communication media is no more that political and economic efforts from media to get much more benefits. Therefore, it is acknowledged that Indonesian films lately put horror and mystic theme beneath in order to get closer with Indonesia culture as the consumers. However, it is issued when the mystic theme influenced along with pornography. Ethics development efforts and law enforcement must be the continuous material to discuss the problem solving.
\end{abstract}

Keywords: film, horror, mystic, pornography

\begin{abstract}
ABSTRAK
Industri film Indonesia telah banyak mengalami masa naik dan turun. Sebagai sebuah industri maka adalah hal yang wajar apabila pelaku film berusaha untuk mengambil keuntungan dari produksi film yang dihasilkan. Berbagai penelitian menunjukkan bahwa pesan-pesan yang dibawa oleh berbagai media komunikasi massa tidak lain adalah sebuah upaya politik ekonomi media untuk mendapatkan keuntungan sebanyakbanyaknya, oleh karenanya suatu hal yang wajar apabila Film Indonesia belakangan ini memasukkan tematema horor dan mistik sebagai upaya untuk lebih dekat dengan budaya khalayak penonton Indonesia yang menjadi konsumennya. Namun, yang harus dipersoalkan adalah ketika segala tema mistik tersebut dimasuki oleh tema lain yaitu pornografi. Oleh karena itu upaya pengembangan etika dan penegakkan hukum saat ini menjadi wacana yang terus menerus diperbicangkan untuk mencari jalan keluarnya.
\end{abstract}

Kata kunci: film, horror, mistik, pornografi 


\section{PENDAHULUAN}

Dunia perfilman di Indonesia saat ini sedang mengalami dilema yang mengingatkan kembali permasalahan film nasional ketika pada masa mati surinya film Indonesia di era tahun 1990-an. Bioskop-bioskop pada dekade itu banyak yang gulung tikar dan film-film Indonesia yang masih tayang di bioskop-bioskop yang masih bertahan sebagian besar didominasi oleh film-film yang mengandung tema-tema yang mengandung unsur erotisme, sedangkan pada bioskop-bioskop berjaringan pada waktu itu, film yang bereder didominasi oleh film-film asing produksi Amerika dan Eropa.

Krisis perfilman Indonesia saat itu, berawal dari kritik yang disampaikan oleh MPEAA (Motion Picture Export Association of America) terhadap kebijakan yang diambil oleh pemerintah Indonesia terkait dengan peredaran film impor di boskokp-bioskop di Indonesia. Keberatan diajukan terutama berkaitan dengan keharusan eksportir asing memasarkan film atau video melalui importir tertentu, pembatasan valuta asing untuk impor film, tingginya bea masuk, dan tambahan biaya-biaya lain. Asosiasi tersebut menginginkan aturan main yang lebih bebas dan membuka peluang berkembangnya pasar film mereka di Indonesia. Lemahnya bargaining position neraca perdagangan Indonesia dengan Amerika menyebabkan dikabulkannya permintaan Amerika untuk membuka pasar perfilman mereka secara lebih bebas di Indonesia, dan sejak saat itulah dimulai era krisis perfilman Indonesia pada dekade tahun 1990 tersebut.

Krisis perfilman pada era tersebut telah mematikan industri film Indonesia. Film-film Indonesia yang diproduksi menurun drastis jumlahnya demikian pula jumlah perusahaan-perusahaan yang meproduksi film juga bertumbangan. Hal ini dapat dilihat dari jumlah film yang beredar di bioskop-bioskop. Berdasarkan angka Departemen Penerangan, 112 judul film Indonesia diproduksi pada tahun 1990/1991, kemudian menurun menjadi 41 judul film pada tahun 1991/1992, dan kembali menurun menjadi 28 film di tahun 1992/1993. Pada Tahun 1996 Ketua GBPSI Johan Tjasmadi mengumumkan bahwa dalam waktu lima tahun sejak tahun 1991 hingga awal 1996, sebanyak 1248 bioskop di Jakarta terpaksa ditutup dan beralih fungsi. Sebagian lagi dijual dan sebagian lagi masih melihat perkembangan, jika keadaan membaik kembali.

Ditengah-tengah krisis tersebut, masih terdapat sineas Indonesia yang bertahan untuk terus memproduksi beberapa jumlah film, tetapi film-film yang beredar didominasi dengan judul-judul yang penuh dengan nuansa erotis bahkan mengarah pada pornografi. Pada tahun 1996 misalnya, film Indonesia disesaki oleh judul film antara lain Ranjang Cinta, Mistik Erotik, Cinta dan Nafsu, Gairah Malam Yang Ketiga, Lampiasan Nafsu, Extasi dan Pengaruh Sex, Gejolak Nafsu dan lain sebagainya.

Disusul pada tahun 1997 yaitu: Permainan yang Panas, Gairah Tabu, Kebebasan Sex, Gigolo, Gairah 100\% dan lain sebaginya, dan pada tahun 1998 masih diwarnai dengan aroma film yang sama yaitu Sentuhan Tabu, Skandal Erotis, Gejolak Sexual. Hal ini cukup dapat dipahami karena jenis film dengan tema-tema yang mengarah pada tema seks yang dapat menjual dan dapat diharapkan membawa keuntungan bagi produsen film, tentu saja ini juga dapat dipakai sebagai dalih perusahaan film untuk dapat bertahan hidup. Tetapi hal ini membawa keprihatinan yang cukup mendalam baik bagi para sineas lain yang punya idealisme yang cukup tinggi dan juga para penikmat film yang menginginkan adanya kualitas film yang lebih baik dari film-film Indonesia.

Serupa tapi tak sama, saat ini pemerintah dan para importir film-film asing khususnya Amerika sedang dalam kondisi tarik ulur masalah pajak yang menurut klaim pemerintah, para importir film tersebut belum melaksanakan kewajiban pembayaran pajak, dan juga ditetapkannya penentuan pajak yang lebih tinggi terhadap film impor di Indonesia. Tarik ulur antara Motion Picture Association dengan Pemerintah Indonesia ini telah mengakibatkan tidak masuknya sebagian film-film produksi 
Amerika terutama film-film dari perusahaan-perusahaan film Amerika yang tergabung dalam asosiasi tersebut. Kosongnya layar-layar bioskop dari sebagian besar film asing ini, sebagian ada yang menganggap adalah peluang bagi film-film produksi Indonesia untuk tampil dan mengambil perhatian penonton film di Indonesia.

Kebangkitan perfilman Indonesia yang dimulai awal tahun 2000-an, setelah masa-masa buram film Indonesia yang telah diuraikan sebelumnya, telah menjadi pemacu semangat untuk terus memproduksi film-film yang berkualitas. Namun perkembangan dalam kurun waktu lima tahun terakhir terdapat kecenderungan meningkatnya produksi film-film bertema horor mistik yang semakinlama film-film tersebut lebih bertujuan untuk menjual erotisme. Seperti sudah banyak diketahui bahwa tema-tema yang menghiasi isi media yang paling menjual adalah tema-tema tentang horor, ketakutan, drama, komedi, dan seks.

Menurut data perfilman Indonesia yang di release oleh Direktorat Perfilman Kementerian Kebudayaan dan Pariwisata Indonesia lewat situs resminya, sejak tahun 2007 sampai dengan sekarang menunjukkan bahwa dalam daftar sepuluh film dengan penonton terbanyak selalu terselip beberapa film dengan genre horor mistik. Pada tahun 2007 diantara sepuluh film Indonesia dengan penonton terbanyak, film horor mistik mendominasi judul-judul film tersebut, yaitu: Terowongan Casablanca (1.200.000 penonton), Film Horor (900.000 penonton), Suster Ngesot The Movie (800.000 penonton), Pulau Hantu (650.000 penonton), Pocong 3 (600.000 penonton), Lantai 13 (550.000 penonton) dan Kuntilanak 2 (550.000 penonton). Tahun 2008 film horor mistik yang masuk dalam sepuluh besar yaitu Tali Pocong Perawan (1.082.081 penonton) dan Hantu Ambulance (862.193 penonton). Pada Tahun 2009 terdapat Air Terjun Pengantin (1.060.058 penonton), Suster Keramas (840.880 penonton) dan Setan Budeg (700.000 penonton). Pada Tahun 2010 terdapat dua film yang masuk dalam sepuluh besar film dengan penonton terbanyak yaitu Pocong Rumah Angker (502.387 penonton) dan Tiran (Mati di Ranjang) dengan 418.347 penonton.

Perkembangan film Indonesia yang mengangkat tema horor mistik membawa kekuatiran yang cukup besar dalam lima tahun terakhir ini. Berawal dari kesuksesan jelangkung-yang dalam Pattisina (2007) mencapai rekor 1,5 juta penonton—maka film-film dengan tema mistik terus berkembang jumlahnya. Tetapi, film-film tersebut punya kecenderungan besar untuk memasukkan tema-tema dengan muatan erotis dan seks yang dibungkus dengan judul-judul berbau mistis dan horor. Seperti layaknya industri fashion, maka film-film bertema seks kembali lagi berbondong-bondong menyerbu bioskop-bioskop Indonesia. Lihatlah beberapa judul-judul film mistik atau horor yang sedang beredar tahun ini yang dicurigai mengandung tendensi terhadap tema-rema seks, yaitu : Arwah Goyang Karawang, Kuntilanak Kesurupan, Pocong Ngesot, Pelet Kuntilanak dan Kalung Jelangkung. Masih ada beberapa judul film dengan tema sejenis yang sedang dalam produksi dan mengantri untuk tayang di bioskop Indonesia.

Alex Sobur (2003) mengatakan bahwa:

Dua tema yang umumnya menimbulkan kecemasan dan perhatian masyarakat ketika disajikan dalam film adalah adegan-adegan seks dan kekerasan. Kadangkala perhatian ini dikemukakan oleh karena penggambarannya bertentangan dengan standar selera baik masyarakat. Namun seringkali kecemasan masyarakat berasal dari keyakinan bahwa isi seperti itu mempunyai efek moral, psikologis dan sosial yang merugikan, khususnya pada generasi muda, dan menimbulkan perilaku antisosial (hal. 127).

Kecurigaan masyarakat bahwa pembuatan film horor mistik hanya kemasan untuk menjual erotisme bukan tanpa alasan, salah satunya dikarenakan bintang-bintang film yang bermain di dalamnya adalah bintang yang punya reputasi sebagai bintang yang sering punya kontroversi seputar sensualitas dan perdebatan porno atau tidak porno dalam masyarakat. Kualitas film bukan lagi menjadi nomor satu, jualan erotisme dalam isi media ditunjang dengan ditampilkannya pemain-pemain dengan predikat sensual. 
Perkembangan perfilman yang diuraikan diatas tentu saja membawa rasa kritisme dalam menyikapinya. Meskipun sudah dapat diduga sebelumnya bahwa fenomena tema-tema seks dalam isi media dengan bungkus horor mistik ini pastilah dilatarbelakangi komersialisme dalam sistem produksi yang memandang bahwa sebuah film tidak lain adalah hanya sebuah komoditi atau barang dagangan yang sudah seharusnya membawa keuntungan bagi para investornya, tetapi perlulah kita telusuri bagaiamana sebenarnya tinjauan produksi pesan tersebut yang terus menerus di produksi dan kemudian direproduksi kembali dalam kajian ilmu komunikasi. Terutama dalam kajian tentang budaya Indonesia dan bagaimana kemudian budaya tersebut ikut dijadikan sebagai barang dagangan melalui tampilan dalam film-film horor khususnya mistik yang beredar di Indonesia saat ini.

\section{Budaya Mistik dan Tema Erotis dalam Film Horor}

Setiap kelompok masyarakat pasti punya kebudayaan sendiri yang menjadi ciri dari kelompok masyarakat tersebut dibanding dengan kelompok lainnya. Budaya menyangkut cara hidup manusia. Secara formal budaya didefinisikan sebagai tatanan pengetahuan, pengalaman, kepercayaan, nilai, sikap, makna, hirarki, agama, waktu, peranan, hubungan ruang, konsep alam semesta, objek-objek materi dan milik yang diperoleh sekelompok besar orang dari generasi ke generasi melalui usaha individu dan kelompok (Porter \& Samovar). Budaya merupakan dasar kita berperilaku, semakin beragam suatu budaya maka semakin beragam pula praktik komunikasinya. Raymond William menggambarkan budaya dalam empat makna yaitu (1) an individual habit of mind; (2) the state of intellectual development of a whole society; (3) the arts and; (4) the whole way of life of a group or people (Milner \& Browit, 2002).

Kebudayaan, menurut Koentjaraningrat (2009), adalah keseluruhan sistem gagasan, tindakan dan hasil karya manusia dalam kehidupan masyarakat yang dijadikan milik diri manusia dengan belajar. Kebudayaan mempunyai tiga wujud yaitu: (1) wujud kebudayaan sebagai suatu kompleks dari ide, gagasan, nilai, norma, peraturan dan sebagainya; (2) wujud kebudayaan sebagai kompleks aktivitas serta tindakan berpola dari manusia dalam masyarakat; (3) wujud kebudayaan sebagai bendabenda hasil karya manusia. Wujud budaya yang pertama adalah wujud ideal dari kebudayaan. Sifatnya abstrak, tidak dapat diraba atau difoto. Lokasinya ada di dalam kepala atau dengan perkataan lain, dalam alam pikiran warga masyarakat tempat kebudayaan bersangkutan hidup. Ide dan gagasan manusia banyak yang hidup bersama dalam suatu masyarakat, memberi jiwa dalam masyarakat itu, gagasan tersebut menjadi suatu sistem oleh karenanya disebut dengan cultural system atau dalam Bahasa Indonesia disebut adat atau adat istiadat untuk bentuk jamaknya.

Dalam suatu budaya terdapat sistem kepercayaan. Budaya memainkan suatu peranan penting dalam pembentukan kepercayaan, semakin pasti kita dalam kepercayaan kita, semakin besar pulalah intensitas kepercayaan tersebut (Porter \& Samovar, 2006). Selanjutnya menurut Koentjaraningrat (2009), dalam adat istiadat terdapat sistem nilai budaya:

Walaupun nilai budaya berfungsi sebagai pedoman hidup manusia dalam masyarakat, tetapi sebagai konsep, suatu nilai budaya itu bersifat sangat umum, mempunyai ruang lingkup yang sangat luas, dan biasanya sulit untuk diterangkan secara rasional dan nyata. Namun justru karena sifatnya yang umum, luas dan tidak konkret itu, maka nilai-nilai budaya dalam suatu kebudayaan berada dalam daerah emosional dari alam jiwa para individu yang menjadi warga dan kebudayaan yang bersangkutan. Selain itu para individu tersebut sejak kecil telah diresapi dengan nilai budaya yang hidup dalam masyarakatnya sehingga konsep-konsep itu sejak lama telah berakar dalam alam jiwa mereka. Itulah sebabnya nilai-nilai budaya dalam suatu kebudayaan tidak dapat diganti dengan nilai-nilai budaya yang lain dalam waktu singkat, dengan cara mendiskusikannya secara rasional.

Sistem religi merupakan salah satu unsur kebudayaan yang mempunyai wujud sebagai sistem keyakinan dan gagasan tentang Tuhan, dewa, roh halus, neraka, surga dan sebagainya, tetapi mempunyai juga wujud berupa upacara, baik yang bersifat musiman maupun yang kadangkala, dan 
selain itu setiap sistem religi juga mempunyai wujud sebagai benda-benda suci dan benda-benda religius. Dalam sistem religi, terdapat dua bahasan pokok yaitu: sistem religi dan sistem ilmu ghaib (Koentjaraningrat, 2009). Dalam sistem religi, emosi keagamaan yang merupakan unsur penting dalam suatu religi bersama dengan tiga unsur lain yaitu: sistem keyakinan, sistem upacara keagamaan, dan suatu umat yang menganut religi itu.

\begin{abstract}
Para ahli antropologi biasanya menaruh perhatian terhadap konsepsi tentang dewa-dewa yang baik maupun yang jahat; sifat dan tanda dewa-dewa; konsepsi tentang makhluk-makhluk halus lainnya seperti roh-roh leluhur, roh-roh lain yang baik maupun yang jahat, hantu dan lain-lain; konsepsi tentang dewa tertinggi dan pencipta alam; masalah terciptanya dunia dan alam (kosmogoni); masalah mengenai bentuk dan sifat-sifat dunia dan alam (kosmologi); konsepsi tentang hidup dan maut; konsepsi tentang dunia roh, dunia akhirat dan lain-lain (hal. 295).
\end{abstract}

Sistem religi dan sistem ilmu ghaib sering tampak sama tetapi sebenarnya berbeda. Koentjaraningrat (2009) menggambarkan ilmu ghaib sebagai berikut:

\begin{abstract}
Dalam ilmu ghaib sering terdapat juga konsepsi-konsepsi dan ajaran-ajarannya; ilmu ghaib juga mempunyai sekelompok manusia yang yakin dan menjalankan ilmu ghaib itu untuk mencapai suatu maksud. Selain itu, upacara ilmu ghaib juga mempunyia aspek-aspek yang sama artinya; ada pemimpin atau pelakunya, yaitu dukun; ada saat-saat tertentu untuk mengadakan upacara (biasanya juga pada harihari keramat); ada peralatan untuk melakukan upacara, dan ada tempat-tempat tertentu untuk pelaksanaan upacara. Akhirnya suatu upacara ilmu ghaib seringkali juga mengandung unsur-unsur upacara yang sama dengan upacara religi pada umumnya. Misalnya orang melakukan ilmu ghaib untuk menambah kekuatan ayam yang hendak diadu dalam suatu pertandingan adu ayam. Untuk itu ia membuat obat ghaib dengan sajian kepada roh-roh, dengan mengucapkan doa kepada dewa-dewa, serta dengan mengucapkan mantera-mantera tertentu, dan dengan puasa. Dengan melakukan hal-hal itu semua ia percaya bahwa obat ghaib untuk ayam jantannya akan mujarab sekali (297).
\end{abstract}

Orang-orang dalam semua budaya tampaknya mempunyai perhatian terhadap hal-hal supernatural yang jelas dalam agama-agama dan praktik-praktik agama mereka (Harris \& Moran). Agama-agama yang berkembang di Indonesia semuanya mengajarkan sikap-sikap kita terhadap kehidupan, kematian, dan hidup sesudah mati. Sementara latar belakang perjalanan masyarakat di Indonesia sangat kental diwarnai oleh ajaran-ajaran kepercayaan nenek moyang kita yaitu animisme, oleh karenanya kehidupan masyarakat Indonesia sangat kental diwarnai oleh budaya yang lebih banyak berkaitan dengan hal-hal yang besifat supernatural atau mistik. Menurut Kamus Besar Bahasa Indonesia, Supernatural berarti ajaib (tidak dapat diterangkan dengan akal sehat); gaib; adikodrati. Mistik berarti (1) subsistem yang ada dalam hampir semua agama dan sistem religi untuk memenuhi hasrat manusia mengalami dan merasakan emosi bersatu dengan Tuhan; tasawuf; suluk; (2) hal gaib yang tidak terjangkau dengan akal manusia yang biasa. Sedangkan dalam oxford Dictionary, Supernatural berarti adjective: (of a manifestation or event) attributed to some force beyond scientific understanding or the laws of nature: a supernatural being. Noun: manifestations or events considered to be of supernatural origin, such as ghosts.

Sejarah bangsa Indonesia menunjukkan bahwa budaya yang melatar belakangi kehidupan masyarakat Indonesia sejak dulu selalu berkaitan dengan hal-hal demikian. Cerminan budaya tersebut banyak dijumpai dalam cerita-cerita atau dongeng-dongeng yang mewarnai sastra Indonesia terutama berkaitan dengan hal-hal yang dilatar belakangi dengan istana sentris. Cerita rakyat maupun dongeng bahkan telah berkembang menjadi mitos yang tidak hanya mengangkat tema tentang dongeng terjadinya sebuah situs, dibangunnya sebuah candi, cerita tentang perbuatan baik dan buruk, bahkan menyentuh hal-hal yang berkaitan dengan cerita keagamaan seperti tokoh-tokoh Wali Songo, dan tentunya yang tidak pernah surut adalah cerita-cerita yang berkaitan dengan keberadaan makhlukmakhluk ghaib yang selalu mewarnai kehidupan masyarakat Indonesia di era yang sudah sangat modern ini. 
Budaya Indonesia yang sangat plural ini juga menyediakan cerita atau mitos tentang makhluk ghaib ini dengan sangat beragam disertai dengan masing-masing ciri dan kharakteristiknya yang istimewa. Jika kita coba inventarisasi jumlah makhluk-makhluk tersebut dari Sabang sampai Merauke, maka jumlahnya akan mencapai puluhan bahkan mungkin ratusan. Keberadaan mereka yang tidak tampak ini sangat terasa nyata kehadirannya dalam kehidupan masyarakat Indonesia sehari-hari.

Dalam Undang Undang Nomor 33 Tahun 2009 tentang Perfilman, budaya bangsa adalah seluruh sistem nilai, gagasan, norma, tindakan, dan hasil karya bangsa Indonesia di seluruh wilayah nusantara dalam kehidupan bermasyarakat, berbangsa, dan bernegara. Seperti yang diuraikan sebelumnya bahwa konteks horor mistik ataupun horor setan yang diangkat dalam tema-tema film di Indonesia tentunya tidak akan lepas dari konteks mistik dari budaya Indonesia. Tentunya kita tidak akan pernah membayangkan bahwa film horor di Indonesia akan mengangkat tema-tema horor yang sangat tidak Indonesia, seperti vampir atau drakula. Tentunya film-film horor Indonesia tidak akan lepas dari tokoh-tokoh seperti pocong, kuntilanak, genderuwo, dan sejenisnya.

\section{Film Horor Mistik dan Tema-tema tentang Pornografi}

Sebenarnya apakah film horor itu? Derry (1977) memberikan beberapa jenis bagaimana kita dapat membedakan film horor dalam tiga subgenre, yaitu horror-of-personality (horor psikologis), horror-of-Armageddon (horor bencana), dan horror-of-the-demonic (horor hantu). Dalam horror-ofpersonality atau horor psikologis, kita berhadapan dengan tokoh-tokoh manusia biasa yang tampak normal, tetapi di akhir film mereka memperlihatkan sisi iblis atau monster mereka. Biasanya mereka adalah individu-individu yang sakit jiwa atau terasing secara sosial. Horror-of-the-armageddon atau horor bencana adalah jenis film horor yang mengangkat ketakutan laten manusia pada hari akhir dunia, atau hari kiamat. Ketiga, horror-of-the-demonic, atau horor hantu, horor jenis ini menawarkan tema tentang dunia (manusia) yang menderita ketakutan karena kekuatan setan menguasai dunia dan mengancam kehidupan umat manusia. Horor yang dibahas penulis disini adalah jenis horor yang masuk dalam sub genre ketiga yang kemudian banyak sekali dijadikan kendaraan untuk mengusung tema-tema yang mengandung unsur pornografi.

Film-film horor yang bermunculan di bioskop-bioskop Indonesia dengan jumlah penonton yang tidak sedikit, membuktikan bahwa masyarakat masih memiliki kepercayaan pada hal-hal yang berbau mistis yang sering diidentikkan dengan hal-hal tradisional. Hal ini memperlihatkan bahwa mitos bangsa Indonesia yang telah masuk ke masa modern dan meninggalkan tradisionalisme telah dibongkar, dengan kenyataan yang menggambarkan dengan jelas bahwa modernitas diterima bersamaan dengan kehadiran nilai-nilai dan hal-hal yang bersifat tradisional.

Mengenai materi-materi tentang erotisme bahkan pornografi tidak hanya dapat kita temui dalam media massa film tetapi juga televisi, koran, majalah, juga video game, maupun musik. Heider dalam bukunya Indonesian cinema: National culture on screen (1991) menyatakan bahwa film horor Indonesia pada masa Orde Baru tidak bisa dilepaskan dari tiga hal, yaitu komedi, seks, dan religi. Ketiganya menjadi formula ampuh yang membuat film-film horor Indonesia digemari penontonnya.

Definisi tentang pornografi mempunyai batasan yang berbeda dalam konteks budaya tertentu. Oleh karenanya, agak sulit untukmemberikan batasan tentang apa itu pornografi. Cakupan materimateri yang disebut sebagai materi yang mengandung muatan pornografi biasanya juga berkutat di area yang disebut erotis. Menurut Encyclopedia of Communication and Information (2001), "Sex in media is not limited to explicit portrayals of intercourse or nudity, but rather may include any representation that portrays or implies sexual behavior, interest, or motivation”. Sungguhpun seks merupakan hal yang sangat universal sifatnya, dihampir semua peradaban dan budaya, seksualitas itu sangat privat, tertutup, dan diatur serta dilambangkan dalam aturan agama dan negara yang ketat. Hampir semua agama memberikan batasan pada kegiatan yang berhubungan dengan seks. 
Di Indonesia sendiri batasan tentang apa yang disebut sebagai porno dan yang bukan masih menjadi perdebatan yang panjang dan berlarut-larut. Budaya masyarakat Indonesia yang sangat beragam tentulah menjadi salah satu faktor terberat dalam menentukan masalah apa yang disebut porno atau tidak. Sehingga ketika aturan norma dan nilai tentang masalah ini akan diangkat sebagai suatu aturan main yang punya batasan yang tegas dalam undang-undang, maka ketika undang-undang pornografi ditetapkan tetap saja diskusi masalah porno dan tidak porno terus berlanjut.

Melihat perkembangan tersebut, maka dapat kita amati bahwa materi-materi seks dalam media massa terus-menerus mengalami pertentangan dengan norma-norma sosial masyarakat dan keduanya juga terus-menerus mencoba menemukan titik temu. Akhirnya norma-norma dalam masyarakat terusmenerus mengalami pergeseran dan membawa perubahan sosial dalam masyarakat. Perubahan sosial terjadi ketika ada kesediaan anggota masyarakat untuk meninggalkan unsur-unsur budaya dalam sistem sosial lama dan mulai beralih menggunakan unsur-unsur budaya dan sistem sosial yang baru (Bungin, 2009). Sebagai sebuah perbandingan, pada tahun 1920-an, Hollywood menentukan standar sanksi self-cnsorship yang tegas yang mungkin saat ini cukup lucu jika ditinjau kembali: tidak boleh ada baju dengan potongan dada rendah, tidak boleh ada pusar, tempat tidur yang terpisah bagi pasangan pernikahan, tidak boleh ada ciuman lebih dari empat detik, kaburkan gambar bila sudah mendekati seks (Straubhaar, La Rose \& Davenport, 2004).

\section{Komodifikasi Budaya dan Etika Komunikasi}

Telah diuraikan di atas bahwa horor mistik adalah bagian dari sebuah budaya, namun ketika budaya tersebut diangkat ke layar lebar, maka budaya tidak lagi ditampilkan apa adanya dengan kekurangan dan kelebihannya, tetapi telah direkayasa dan dikonstruksi sedemikian rupa demi kepentingan ekonomi. Pertanyaan apakah media merefleksikan realitas? Maka para humanis melihat bahwa isi media sebagai bagian integral dari budaya nyata, bukan sebagai sesuatu yang dipisahkan dari budaya (Shoemaker \& Reese, 1991). Tetapi dalam politik ekonomi, maka isi media merupakan komoditas budaya dari sistem kapitalis. Konstruksi sosial media massa mampu membangun persepsi penonton mengenai ketakutan, horor, dan kengerian, padahal seperti yang kita tahu cerita dalam film yang ditayangkan hanya konstruksi yang dibentuk oleh media massa yang direkayasa melalui kecanggihan teknologi (Bungin, 2009).

Kesenangan yang diterima penonton terjadi karena film horor Indonesia menghadirkan gambaran-gambaran yang tidak pernah muncul dalam film-film di luar horor. Seks, kekerasan dan halhal yang selama ini tidak ingin dilihat dan disajikan oleh film-film di luar horor. Horor menjadi tempat bagi hal-hal yang bersifat tabu, terlarang, berbahaya, menjijikkan atau pun menakutkan, muncul dan menjadi sesuatu yang penting. Dalam film horor, hasrat-hasrat terpendam manusia, seperti hasrat seksual, hasrat akan uang dan kekuasaan ditampilkan secara langsung dan terbuka. Singkatnya, filmfilm horor menjadi tempat dimana logika yang paling tidak masuk akalpun dapat ditampilkan. Efek buruk yang ditakutkan dari tayangan mistik adalah selain berdampak pada kerusakan kognitif masyarakat, terutama anak-anak, bahaya terbesar dari tayangan mistik dan tahayul adalah pada kerusakan sikap dan perilaku.

Tetapi ketakutan terhadap dampak buruk dari media seringkali tidak sebanding dengan kesenangan semu yang diterima oleh khalayak. Kesenangan yang diterima oleh khalayak ditangkap oleh para pelaku industri perfilman untuk mendapatkan keuntungan. Menanggapi ideologi kapitalisme, Zizek (dalam Milner \& Browit, 2002), menggambarkan bahwa "capital itself is ultimate power of "deterritorialization", which undermines every fixed identity, late capitalism is the power that weakens the traditional fixity of ideological position (patriarchy, fixed sexual roles, etc)',so as to remove all possible barriers to the "unbrilled commodification of everyday life" (hal. 85). 
Pada perusahaan-perusahaan media yang dimiliki secara privat, semuanya mengarah pada pentingnya arus profit, termasuk didalamnya content dari media dan apa yang dicari oleh khalayak. Pemilik media harus menghasilkan profit setelah membayar semua biaya-biaya operasional dan pajakpajak. Mereka juga harus membayar modal awal, uang yang dipinjam dari bank atau investor mereka yang menempatkan peralatan-peralatan produksi dengan bunga (Straubhaar, La Rose \& Davenport, 2004). Formula untuk tetap menghasilkan profit cukup mudah. Pembayaran yang diterima dari konsumen dan para pengiklan merupakan dasara ekonomi dari perusahaan, uang yang dihasilkan dari pembayaran ini harus melebihi biaya yang dikeluarkan untuk content, distribusi, operasional harian, pajak dan investasi. Dalam dunia kapitalisme, hiburan dan bahkan budaya telah menjelma menjadi industri

Adorno \& Horkheimer (1995) mengatakan bahwa films, radio and magazines make up system which is uniform as a whole and in every part...movies and radio need no longer pretend to be art. The truth that they are just businessis is made into an ideology in order to justify the rubbish they deliberately produce." Hal ini adalah sebuah penggambaran bahwa budaya yang diusung dalam ideologi kapitalis telah membuat budaya itu sendiri tidak punya ruh dan akhirnya hanya menjadi budaya yang seragam. Bungin (2009) melihat fenomena isi media dengan muatan sex sebagai bagian dari budaya massa, menurutnya:

\begin{abstract}
Budaya massa, terutama yang diproduksi oleh media massa diproduksi oleh media massa diproduksi menggunakan biaya yang cukup besar, karena itu dana yang besar itu harus menghasilkan keuntungan untuk kontinuitas budaya massa itu sendiri, karena itu budaya massa diproduksi secara komersial agar tidak saja menjadi jaminan keberlangsungan sebuah kegiatan budaya massa namun juga menghasilkan keuntungan bagi kapital yang diinvestasikan pada kegiatan tersebut. (hal, 78)
\end{abstract}

Industrialisasi tidak hanya memungkinkan proses massifikasi, yang menuntut standarisasi produk budaya dan homogenisasi cita rasa, tapi juga ia telah membawa perkembangan baru dengan semakin terbentangnya peluang pasar. Inilah yang menandai komersialisasi atas produk budaya. Dengan komersialisasi, produk budaya (massa) berubah seirama dengan percepatan tuntutan komersial. Maka, massa pun berubah menjadi tempat pemasaran produk budaya dan sasaran berondongan iklan. Untuk alasan komersialisasi inilah, selera dan cita rasa masyarakat pun dikemas dan dikonstruksi menurut logika pasar. Arus industri kebudayaan yang amat bertumpu pada pasar ini, dan atas nama segmentasi pasar, kemudian mengaburkan batas-batas perbedaan kelas, wilayah, profesi, dan berbagai kemajemukan yang ada di masyarakat.

Kapitalisme telah menciptakan kesadaran palsu karena semua hal dijadikan sebagai komoditas. Realitas budaya dikonstruksi bahkan didekonstruksikan dalam media massa, untuk kemudian disebarkan kepada khalayak. Khalayak dapat saja mempersepsikan bahwa yang tampak dalam media itulah realitas, sehingga akhirnya khalayak secara serempak mengadopsi nilai-nilai dan realitas yang ditampilkan dalam media, sehingga timbulah keseragaman budaya dalam masyarakat. Keseragaman budaya tampak dari sikap dan perilaku, tetapi pada hakekatnya keseragaman itu telah ada dalam tataran kognitif masyarakat. Menurut Agger (dalam Bungin, 2009), dalam bahasan tentang budaya populer, maka seksualitas dalam film horor mistik tidak lebih merupakan bagian dari budaya populer, kebudayaan populer lebih banyak berpengaruh pada kelompok orang muda dan menjadi pusat ideologi masyarakat dan kebudayaan, padahal budaya populer terus menjadi kontradiksi dan perdebatan. Menurut Bungin (2009), budaya massa dibentuk disebabkan oleh: (1) tuntutan industri kepada pencipta untuk menghasilkan karya yang banyak dalam tempo singkat. Maka si pencipta untuk menghasilkan karya yang banyak dalam tempo singkat, tak sempat lagi berpikir, dan dengan secepatnya menyelesaikan karyanya. Mereka memiliki target produksi yang harus dicapai dalam waktu tertentu; dan (2) karena budaya massa cenderung 'latah' menyulap atau meniru segala sesuatu yang sedang naik daun atau laris, sehingga media berlomba untuk mencari keuntungan sebesarbesarnya. 
Theodore Adorno dan Max Horkheimer mengatakan budaya industri adalah media tipuan. Mereka percaya bahwa hilangnya kepribadian yang tulus seperti kemampuan menggambarkan keadaan yang nyata karena budaya telah berubah menjadi alat industri serta menjadi produk standar ekonomi kapitalis. Dunia hiburan telah menjadi sebuah proses reproduksi kepuasan manusia dalam media tipuan. Hampir tidak ada lagi perbedaan antara kehidupan nyata dan dunia yang digambarkan dalam film yang dirancang dengan efek suara dengan tingkat ilusi yang sempurna sehingga tak terkesan imaginatif. Dalam pandangan politik ekonomi media, Mosco (dalam Barret \& Newbold, 1995) menyampaikan salah satu konsep dari tiga konsepnya tentang politik ekonomi, yaitu komodifikasi. Menurutnya komodifikasi adalah : the process of taking goods and services which are valued for their use, and transforming them into commodities which are valued for what they can earn in the market place (hal. 187).

Bungin (2009) mengategorikan tayangan mistik dengan menitik beratkan pada tayangan televisi. Menurutnya tayangan mistik dapat dikategorikan menjadi tiga bentuk: (1) mistik-semi sains, yaitu mistik yang berhubungan dengan fiksi ilmiah, dimana menurutnya mistik disini masih mengandung kemudngkinan adanya kebenaran; (2) mistik fiksi, yaitu film mistik hiburan yang tidak masuk akal, bersifat fiksi, atau hanya sebuah fiksi yang difilmkan untuk menciptakan dan menyajikan misteri. Contoh yang diberikan misalnya: Batman, Harry Potter, Misteri Gunung Merapi, dan lainnya; (3) mistik-horor, yaitu film mistik yang lebih banyak mengeksploitasi dunia lain, seperti hubungannya dengan jin, setan, santet, kekuatan-kekuatan supranatural seseorang, kematian tidak wajar, balas dendam, penyiksaan, dan sebagainya.

Menurut Bungin (2009), paling tidak persoalan porno di masyarakat harus dapat menjawab bahwa pemaknaan porno di suatu masyarakat dapat menggeserkan konseptualisasi seks secara normatif, dimana seks sebagai sesuatu yang sakral menjadi seks yang dipahami sebagai komoditas. Menurut Nightinghale (1996): "in the financial economy, the cultural commodity has a monetary value and in the cultural economy its value is measured in "meanings, pleasure and social identities" (hal. 56).

\section{Kebebasan Berekspresi dan Sensor Film Indonesia}

Industri perfilman adalah salah satu industri kreatif yang dapat menunjang perekonomian negara. Industri ini utamanya harus ditunjang oleh adanya pendayagunaan kreatifitas bagi para pelakunya. Pada dasarnya kerangka berpikir utama dari dibuatnya sebuah film adalah karena diakuinya hak atas kebebasan untuk berekspresi seperti yang disampaikan dalam Piagam Perserikatan Bangsa-Bangsa (Universal Declaration of Human Rights) yaitu: Everyone has the right to freedom of opinion and expression; this right includes freedom to hold opinions without interference and to seek, receive and impart information and ideas through any media and regardless of frontiers.

Oleh karenanya apa yang diungkapkan, digambarkan dan dinyatakan dalam sebuah film baik suara, musik, dialog, gambar, plot adegan, dan sebagainya. Adalah salah satu perwujudan pengakuan dari Hak Asasi Manusia. Indonesia sebagai sebuah negara demokrasi sudah tentu harus memberikan pengakuan terhadap kebebasan berekspresi ini. Pengakuan tersebut telah dituangkan dalam Konstitusi Negara Republik Indonesia yaitu Undang-Undang Dasar 1945 khususnya pada pasal 28F yaitu: "Setiap orang berhak untuk berkomunikasi dan memperoleh informasi untuk mengembangkan pribadi dan lingkungan sosialnya, serta berhak untuk mencari, memperoleh, memiliki, menyimpan, mengolah, dan menyampaikan informasi dengan menggunakan segala jenis saluran yang tersedia.”

Kebebasan dari setiap asasi manusia tentunya punya batasan-batasan yang harus dapat menghargai dan mengakui kebebasan dan keberadaan manusia lainnya secara sama dan setara. Oleh karenanya secara normatif setiap lingkungan budaya harus menentukan nilai-nilai dalam setiap budayanya, dan tentunya nilai tersebut berbeda di tiap budaya. Seperti yang telah diatur dalam 
Undang-Undang Nomor 33 Tahun 2009 tentang Perfilman di Indonesia disebutkan bahwa (Pasal 5): Kegiatan perfilman dan usaha perfilman dilakukan berdasarkan kebebasan berkreasi, berinovasi, dan berkarya dengan menjunjung tinggi nilai-nilai agama, etika, moral, kesusilaan, dan budaya bangsa. Sayangnya nilai-nilai agama, etika, moral, kesusilaan dan budaya bangsa seringkali tidak punya ukuran-ukuran pasti, sehingga seringkali terjadi diskusi yang sangat panjang dalam menentukan mana yang sesuai dan mana yang tidak sesuai.

Dalam bahasan tentang bagaimana isi media melalui film telah dianggap menampilkan pornografi, maka sebenarnya materi-materi tersebut dapat ditolak. Menurut Ogien (dalam Haryatmoko, 2007) pornografi dapat didefinisikan sebagai representasi eksplisit (gambar, tulisan, lukisan dan foto) dari aktivitas seksual atau hal yang tidak senonoh, mesum atau cabul yang dimaksudkan untuk dikomunikasikan ke publik. Menurutnya, Tiga alasan utama menolak pornografi antara lain adalah, pertama untuk perlindungan terhadap orang muda atau anak-anak; kedua, mencegah perendahan martabat perempuan; ketiga, mencegah sifat subversifnya yang cenderung menhnacurkan tatanan nilai seksual keluarga dan masyarakat. Pornografi dalam media massa ditakutkan akan membawa dampak yang negatif karena akan dianggap menimbulkan rangsangan seksual sehingga akan mendorong perilaku yang membahayakan orang lain.

Untuk memfilter materi-materi pornografi, pemerintah menyerahkan gunting sensornya pada Lembaga Sensor Film (LSF). Menurut Undang-Undang Nomor 33 Tahun 2009 tentang Perfilman, sensor film diartikan sebagai kegiatan penelitian, penilaian, dan penentuan kelayakan film dan iklan film untuk dipertunjukkan kepada khalayak umum. Dari pengertian itu dapat disimpulkan bahwa titik berat kegiatan sensor film terletak pada tahap-tahap kegiatan: (1) penelitian; (2) penilaian, dan (3) penentuan kelayakannya untuk dipertunjukkan kepada khalayak umum.

Dalam melakukan penyensoran terdapat 4 (empat) elemen dasar yang telah ditetapkan oleh Peraturan Pemerintah RI Nomor 7 Tahun 1994, yaitu: penilaian dari sisi keagamaan, ideologi dan politik, sosial budaya masyarakat Indonesia, dan dari sisi ketertiban umum. Dari sisi sosial budaya apabila ada film yang dinilai dapat merusak dan membahayakan, karena adanya ejekan dan/atau menimbulkan tanggapan yang keliru terhadap sistem nilai budaya antarsuku di Indonesia perlu dilakukan pemotongan atau penolakan. Demikian pula halnya terhadap film yang dapat merusak akhlak, budi pekerti, etika, moral, disiplin masyarakat.

Kriteria-kriteria yang dapat dilakukan pemotongan atau dihapus antara lain adalah: (1) adegan seorang pria atau wanita dalam keadaan atau mengesankan telanjang bulat, baik dilihat dari depan, samping, atau dari belakang; (2) close-up alat vital, paha, buah dada, atau pantat, baik dengan penutup maupun tanpa penutup; (3) adegan ciuman yang merangsang, baik oleh pasangan yang berlainan jenis maupun sesama jenis yang dilakukan dengan penuh birahi; (4) adegan, gerakan atau suara persenggamaan atau yang memberikan kesan persenggamaan, baik oleh manusia maupun oleh hewan, dalam sikap bagaimanapun, secara terang-terangan atau terselubung; (5) gerakan atau perbuatan onani, lesbian, homo atau oral sex; (6) adegan melahirkan, baik manusia maupun hewan, yang dapat menimbulkan birahi; (7) menampilkan alat-alat kontrasepsi yang tidak sesuai dengan fungsi yang seharusnya atau tidak pada tempatnya; atau (8) adegan-adegan yang dapat menimbulkan kesan tidak etis.

Kriteria-kriteria tersebut disebutkan dengan rinci dan jelas, dan hal ini akhirnya menimbulkan pertanyaan tentang bagaimana dengan kebebasan berekspresi yang manjadi bagian utama bagi terciptanya sebuah karya sinematografi ini. Banyak sineas film tidak setuju dengan aturan sensor yang selama ini telah dijalankan oleh LSF. Menurut mereka, pendewasaan penonton film hendaknya diserahkan kepada penonton itu sendiri dalam memutuskan mana film yang layak untuk ditonton atau tidak. Pemerintah diharapkan untuk menetapkan sistem yang lebih tegas terhadap kriteria usia penonton dan jenis film yang ditonton. 


\section{PENUTUP}

Mistik dan masyarakat Indonesia adalah dua hal yang tidak bisa dipisahkan. Budaya Indonesia menyimpan begitu banyak kandungan energi yang terkait dengan wilayah mistik. Olehkarenanya ketika tema mistik diangkat dalam sebuah karya film maka adalah hal yang sangat wajar, tetapi ketika tema mistik mulai dijadikan tumpangan untuk menjual materi-materi yang menjurus pornografi dan pengenyampingan nilai-nilai dan etika bangsa, maka hal ini terntulah harus dicermati lebih lanjut. Permasalahan dan perdebatan mengenai pornografi yang belum selesai menjadi hal lain yang menambah keruwetan dalam perfilman Indonesia. Film yang menjadi bagian dari perputaran modal yang cukup besar menuntut produsen film untuk meneguk keuntungan dari barang dagangannya. Sehingga budaya mistik dalam dunia perfilman tidak ubahnya seperti sebuah komoditi yang punya nilai jual cukup tinggi, utamanya bila ditambah dengan bumbu-bumbu erotis dan menjurus kepada pornografi. Indonesia sebagai negara demokrasi mengakui adanya kebebasan berkespresi tetapi pemeliharaan nilai-nilai luhur rupanya belum bisa dilepaskan sepenuhnya oleh pemerintah kepada masyarakat, sehingga sampai saat ini gunting sensor dari LSF menjadi satu-satunya pintu bagi produsen film agar filmnya dapat dianggap layak tonton di bisokop-bioskop di Indonesia.

\section{DAFTAR PUSTAKA}

Adorno, T. W., \& Horkheimer, M. (1995). The culture industry: Enlightenment as mass deception. Dalam O. B. Barret \& C. Newbold (Eds.), Approaches to media: A reader, hal. 77. London: Arnold.

Barret, O. B., \& Newbold, C. (1995). Aproaches to media: A reader. London: Arnold.

Bungin, B. (2009). Sosiologi komunikasi, teori paradigma, dan diskursus teknologi komunikasi di masyarakat. Kencana.

Derry, C. (1977). Dark dreams: A psychological history of the modern horror film. Ohio: Barnes Noble.

Encyclopedia of Communication and Information. (2001). USA: Macmillan Reference.

Harris, P. R., \& Moran, R. T. (2006). Memahami perbedaan-perbedaan budaya. Dalam D. Mulyana \& J. Rakhmat (Eds.), Komunikasi antarbudaya: Panduan berkomunikasi dengan orang-orang berbeda budaya (hal. 62). Bandung: Remaja Rosdakarya.

Haryatmoko. (2007). Etika komunikasi, manipulasi media, kekerasan dan pornografi. Kanisius.

Heider, K. G. (1991). Indonesian cinema: National culture on screen. Honolulu: University of Hawaii Press.

Ibrahim, M. D. (1996). Citra perempuan dalam media: Eksploitasi dan sensasi sadistik. Dalam I. S. Ibrahim (Ed.), Lifestyle ecstasy: Kebudayaan pop dalam masyarakat komoditas Indonesia. Yogyakarta: Jalasutra.

Koentjaraningrat. (2009). Pengantar ilmu antropologi. Jakarta: Rineka Cipta. 
Milner, A., \& Browit, J. (2002). Contemporary cultural theory: An introduction (3rd ed.). London: Routledge.

Nighthale, V. (1996). Studying audience: The sock of the real. London: Routledge.

Republik Indonesia. (2009). Undang-Undang Nomor 33 tahun 2009 tentang Perfilman. Jakarta.

Republik Indonesia. (1994). Peraturan Pemerintah Republik Indonesia Nomor 7 Tahun 1994 tentang Lembaga Sensor Film. Jakarta: Lembaran negara Republik Indonesia Tahun 1994 Nomor 12.

Pattisina, E. C. (2007, Maret). Selamat datang di republik hantu. KOMPAS, 25 Maret 2007.

Porter, R. E., \& Samovar, L. A. (2006). Suatu pendekatan terhadap komunikasi antar budaya. Dalam D. Mulyana \& J. Rakhmat (Eds.), Komunikasi antarbudaya: Panduan berkomunikasi dengan orang-orang berbeda budaya (hal. 18). Bandung: Remaja Rosdakarya.

Sabidy, D. A. (2005). Xxxxxxx. Jurnal Thesis 2004: Jurnal Penelitian Ilmu Komunikasi, Volume IV/No. 1 Januari-April 2005, Hal. 55.

Shoemaker, P. J., \& Reese, S. D. (1991). Mediating the message: Theories of influences on mass media content. New York: Longman.

Sobur, A. (2003). Semiotika komunikasi. Bandung: Remaja Rosdakarya.

Straubhaar, J., La Rose, R., \& Davenport, L. (2004). Media now, understanding media, culture, and technology (4th ed.). USA: Wadsworth/Thomson Learning. 